\title{
A HEPARIN-PRECIPITABLE FRACTION OF HUMAN PLASMA. I. ISOLATION AND CHARACTERIZATION OF THE FRACTION ${ }^{1}$
}

\author{
BY RICHARD T. SMITH 2 AND RICHARD W. VON KORFF 3 \\ (From the Pediatric Research Laboratories of the Variety Club Heart Hospital, and the De- \\ partment of Pediatrics, University of Minnesota Medical School, Minneapolis, Minn.)
}

(Submitted for publication October 22, 1956; accepted December 13, 1956)

Evidence has accumulated indicating that the fibrinoid deposits found in histopathologic material in certain human diseases-for example, acute lupus erythematosus and polyarteritis-may be derived, at least in part, from fibrinogen, fibrin, or a closely related protein $(1,2)$. Studies of the conditions under which similar deposits are laid down in the blood vessels of rabbits during the generalized Shwartzman reaction $(3,4)$ and after injection of gram-negative bacterial endotoxin in combination with acidic polymers of large molecular size $(5,6)$, have provided an experimental model for studying the origin of these deposits. In the rabbit a direct correlation between the disappearance of fibrinogen from the circulating blood and the appearance of fibrinoid within the glomerular blood vessels was observed, and the suggestion was made that endotoxin produced an increase in the in vivo precipitability of fibrinogen by acidic polymers $(7,8)$. It was shown that within less than one hour after an intravenous injection of endotoxin, a change in the stability of fibrinogen occurred which was manifested by the cold-insolubility of this protein in the presence of heparin $(7,9)$. It seemed possible that this heparin-precipitable form of fibrinogen might represent, in the rabbit, a precursor of fibrinoid, and a study of the occurrence of a similar cold-insoluble, heparin-precipitable component in human plasma was therefore undertaken.

This presentation is concerned with attempts to characterize the fraction.

\footnotetext{
1 Aided in part by grants from the American Heart Association, the Minnesota Heart Association, and the Graduate School Research Fund of the University of Minnesota.

2 Work performed as Helen Hay Whitney Foundation Research Fellow, and as a Senior Investigator of the Arthritis and Rheumatism Foundation.

8 Established Investigator of the Minnesota Heart Association.
}

Data will be presented which 1) describe the essential features necessary for the precipitation reaction to occur, 2) define the solubility in terms of $\mathrm{pH}$, ionic strength, and a requirement for specific cations, and 3) establish a close relationship between the fraction and fibrinogen. The nature of the heparin-fibrinogen combination and its possible relationships to previously described fibrinogen fractions are discussed. Preliminary accounts of these observations have been presented elsewhere $(10,11)$.

\section{MATERIALS AND METHODS}

Heparin-precipitable fraction (HPF). In most of the experiments the precipitation reaction was studied utilizing the heparinized plasma of patients with various inflammatory diseases, in whose plasma prior measurements had detected relatively large amounts of the fraction. Single or pooled samples of such plasma containing a final heparin concentration of $0.1 \mathrm{mg}$. per $\mathrm{ml}$. were employed unless otherwise stated.

For experiments in which the effect of various reagents upon the yield of precipitate from heparinized plasma was determined, the reagents were added directly to aliquots of the heparinized plasma prior to cooling to $2^{\circ} \mathrm{C}$. The $\mathrm{pH}$ of heparinized plasma at room temperature ranged between 7.8 and 7.95. The plasma-reagent mixture was then chilled at $2^{\circ} \mathrm{C}$ for 18 hours. The resulting precipitate was separated by centrifugation in the International refrigerated centrifuge. It was washed twice with cold $0.05 \mathrm{M}, \mathrm{pH} 7.4$ phosphate buffer and collected by centrifugation. The twice-washed precipitates were then dissolved in buffer at $37^{\circ} \mathrm{C}$ and the protein content was measured by the biuret technique (12) employing a Coleman Jr. spectrophotometer. This method is presented in more detail in the accompanying paper.

For experiments in which the solubility of isolated fraction at varying ionic strength and $\mathrm{pH}$ was determined, the twice-washed precipitates from heparinized plasma were dissolved in buffer solutions of various ionic strength and $\mathrm{pH}$ values at $37^{\circ} \mathrm{C}$. The resulting solutions were then chilled' at $2^{\circ} \mathrm{C}$ for an additional 18 hours. Solubility was determined by measuring the protein content of the precipitate. 
Anticoagulants. Heparin used for most of these studies was a solution of commercial heparin containing 10 mg. per $\mathrm{ml}$. A purified sodium heparinate preparation (Upjohn, lot No. DX-629) was used in some experiments. Sodium citrate was employed at a final concentration of 0.4 per cent. Disodium ethylenediamine tetraacetate ("Versenate") as a 0.05 molar solution was used at the ratio of $0.5 \mathrm{ml}$. for each $5 \mathrm{ml}$. of blood. Solutions of sodium polymannuronic acid sulfate, "1148A," chitin sulfate, alginic acid sulfate, containing $10 \mathrm{mg}$. per $\mathrm{ml}$. were used at the ratio of $0.1 \mathrm{ml}$. for each $5 \mathrm{ml}$. blood. These polymers were obtained through the courtesy of the Upjohn Company, Kalamazoo, Michigan. Chondroitin sulfate was generously supplied by Dr. G. Berenson, New Orleans.

Clottability was determined by adding thrombin to a mixture containing $2.0 \mathrm{ml}$. of the twice-washed fraction dissolved in pH 7.4, $0.05 \mathrm{M}$ phosphate buffer, and $5 \mathrm{ml}$. phosphate-saline buffer. Since maximal clotting was produced by adding 30 units of thrombin, this amount was used. The weight of the clot was then determined, and the result expressed as per cent of total protein. No correction for occlusion (13) of other proteins was made.

Electrophoresis was performed by the zone method on paper, utilizing a Spinco Model R, paper strip apparatus, and $\mathrm{pH} 8.6$, ionic strength 0.1 veronal buffer. To assure maximum solubility of the fraction, the chamber of the electrophoresis apparatus was placed in an incubator at $37^{\circ} \mathrm{C}$ for most of these studies. The fraction was isolated as described above, and redissolved at $37^{\circ} \mathrm{C}$ in veronal buffer. Ten microliters of the solution was then applied immediately to the paper strips. Most runs were made at 15 milliamps for 6 hours. The strips were heat-fixed and stained with bromphenol blue.

Ultracentrifugation studies were performed in collaboration with Dr. D. R. Briggs, of the Department of Agricultural Biochemistry of the University of Minnesota. All runs were made in a Model E Spinco analytical ultracentrifuge at 59,780 revolutions per minute at room temperature. Sedimentation constants $\left(\mathrm{S}_{20 \mathrm{w}}\right)$ were calculated by standard methods. The fraction was prepared for these studies as for electrophoresis, except that it was dissolved in $0.5 \mathrm{M} \mathrm{NaCl}$ at $\mathrm{pH} 7.4$.

\section{RESULTS}

\section{General observations}

Heparinized plasma obtained from a patient with acute rheumatic fever or other acute inflammatory disease, when placed at $2^{\circ} \mathrm{C}$ for 18 hours, yields a coarse precipitate. Within approximately 20 minutes after chilling the plasma an opalescence appears; a precipitate then separates and settles out within a 3 to 6 -hour period. The precipitates vary somewhat in texture, consisting at times
TABLE I

Precipitation occurring in plasma at $2^{\circ} \mathrm{C}$ with various anticoagulants

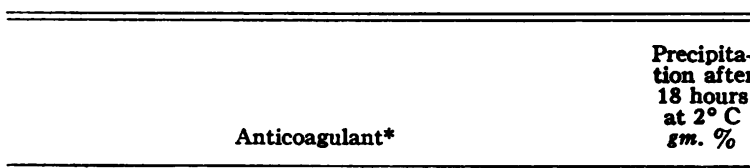

(A) Calcium binding agents

Disodium ethylenediamine tetraacetic acid, $0.1 \mathrm{mM} / \mathrm{ml}$.

Sodium citrate, $0.05 \mathrm{mM} / \mathrm{ml}$.

Ammonium and potassium oxalate mixture, dry

(B) Heparin plus calcium binding agent

Serum; $0.2 \mathrm{mg} . / \mathrm{ml}$. sodium heparin added before chilling

Sodium citrate, $0.05 \mathrm{mM} / \mathrm{ml}$.; sodium heparin, $0.2 \mathrm{mg} . / \mathrm{ml}$. added before chilling

Disodium ethylenediamine tetraacetic acetate, $0.1 \mathrm{mM} / \mathrm{ml}$; sodium heparin, $0.2 \mathrm{mg} . / \mathrm{ml}$., added before chilling

(C) Sulfated polymers

Sodium heparin, $0.2 \mathrm{mg} . / \mathrm{ml}$.

Sodium polymannuronic acid sulfate, $\mathbf{0 . 2}$ $\mathrm{mg} . / \mathrm{ml}$.

$1148 \mathrm{~A}, 0.2 \mathrm{mg} . / \mathrm{ml}$.

Alginic acid sulfate, $0.2 \mathrm{mg} . / \mathrm{ml}$.

Chitin sulfate, $0.2 \mathrm{mg} . / \mathrm{ml}$.

Sodium citrate, $0.05 \mathrm{mM} / \mathrm{ml}$. plus chondroitin sulfate, $0.2 \mathrm{mg} . / \mathrm{ml}$.

* Blood from an acutely ill patient was drawn into tubes containing the final concentration of anticoagulant indicated. The amount of precipitate in the plasma was measured after 18 hours at $2^{\circ} \mathrm{C}$.

of heavy floccules, but on other occasions having a fibrillar appearance. Warming to $37^{\circ} \mathrm{C}$ for a few minutes redissolves the precipitate. No precipitation is observed at 18 hours in serum, or in citrated, oxalated, or versenated plasma (Table I [A]). However, when heparin is added to ci-

TABLE II

Influence of heparin concentration on cold precipitation from plasma

\begin{tabular}{cccccccc}
\hline & \multicolumn{8}{c}{$\begin{array}{c}\text { Precipitate } \\
\text { gm. \% }\end{array}$} \\
\cline { 2 - 8 } Patient* & \multicolumn{7}{c}{ Heparin concentration, mg./ml. whole blood } \\
\cline { 2 - 8 } & 0.01 & 0.05 & 0.075 & 0.10 & 0.15 & 0.20 & 0.50 \\
\hline A & 0.11 & 0.30 & & 0.37 & & 0.20 & 0.19 \\
B & & 0.53 & 0.60 & 0.64 & 0.38 & 0.24 & 0.19 \\
C & & 0.10 & 0.16 & 0.16 & 0.15 & 0.07 & \\
& & 0.10 & & & & & \\
\end{tabular}

* Five ml. of blood was taken from the patient and placed in tubes containing heparin in $0.1 \mathrm{ml}$. to give the final concentration indicated. The precipitate formed after 18 hours at $2^{\circ} \mathrm{C}$ was measured. 
trated or versenated plasma precipitation occurs (Table I $[\mathrm{B}]$ ), indicating that the component is present in decalcified plasma, but soluble at $2^{\circ} \mathrm{C}$ unless heparin is added.

Multiple washings of the precipitate from heparinized plasma with $\mathrm{pH} 7.4$ phosphate buffer at $2^{\circ} \mathrm{C}$ do not significantly alter its solubility. It appears, therefore, that heparin combines with the plasma component forming a complex, insoluble at $2^{\circ} \mathrm{C}$, and that precipitation does not occur as a result of changes in the solvent on addition of heparin.

Other heparin-like anticoagulant polysaccharides, such as alginic acid sulfate, chitin sulfate, $1148 \mathrm{~A}$, and polymannuronic acid sulfate, also produced a cold-precipitate which, although varying in amount, did not differ qualitatively from that observed in heparinized plasma (Table I [C]). Chondroitin sulfate, when added to citrated plasma, resulted in some cold-precipitation. Twice-washed precipitates added to washed RBC produced rouleaux formation regularly, and when added to normal oxalated blood greatly accelerated the erythrocyte sedimentation rate.

\section{The effect of heparin concentration on HPF solu- bility in plasma}

The amount of precipitation occurring in the plasmas of acutely ill patients containing varying amounts of heparin is illustrated in Table II. The data show a narrow range of heparin concentration at which maximum precipitate yield is obtained. The optimal concentration for maximum precipitate yield in this and similar experiments was in the range of 0.05 to $0.15 \mathrm{mg}$. heparin per $\mathrm{ml}$. of whole blood.

TABLE III

Effect of ionic strength on precipitation from heparinized plasma*

\begin{tabular}{cc}
\hline \hline $\begin{array}{c}\text { Ionic strength } \\
\Delta \mu\end{array}$ & $\begin{array}{c}\text { Precipitate } \\
\text { gm. \% }\end{array}$ \\
\hline None & 0.60 \\
0.017 & 0.59 \\
0.043 & 0.43 \\
0.085 & 0.08 \\
0.171 & 0.06
\end{tabular}

* To $1.8 \mathrm{ml}$. heparinized plasma taken from an acutely ill patient, $0.2 \mathrm{ml}$. of an $\mathrm{NaCl}$ solution was added to give the final added $\Delta$ ionic strength indicated. After 18 hours at $2^{\circ} \mathrm{C}$ the amount of precipitate in these plasmas was determined.
TABLE IV

Effect of $p H$ on precipitation from heparinized plasma

\begin{tabular}{cc}
\hline \hline $\begin{array}{c}\text { Final } \mathrm{pH} \text { of } \\
\text { plasma* }\end{array}$ & $\begin{array}{c}\text { Precipitate } \\
\text { gm.\% }\end{array}$ \\
\hline 7.9 (untreated) & 0.50 \\
7.5 & 0.64 \\
7.0 & 0.68 \\
6.7 & 0.50
\end{tabular}

* To heparinized plasma taken from an acutely ill patient, $0.1 \mathrm{~N} \mathrm{HCl}$ was added in amounts required to give indicated final $\mathrm{pH}$ value measured at room temperature. After 18 hours at $2^{\circ} \mathrm{C}$ the amount of precipitate in the plasmas was determined.

\section{The effect of ionic strength and $p H$ on $H P F$ solubility}

The effect of ionic strength and $\mathrm{pH}$ alterations of heparinized plasma on precipitate yield is illustrated by a typical experiment shown in Table III. In these experiments various concentrations of $\mathrm{NaCl}$ were added to plasma prior to chilling. The yield of HPF decreased progressively with increasing ionic strength.

The desired final $\mathrm{pH}$ of heparinized plasma was obtained by stepwise addition of $0.1 \mathrm{~N}$ hydrochloric acid. In an illustrative experiment recorded in Table IV, final $\mathrm{pH}$ values at room temperature were 6.7, 7.0, 7.5, and 7.9. Maximum precipitate yield from plasma after chilling to $2^{\circ} \mathrm{C}$ for 18 hours was obtained at $\mathrm{pH} 7.0$.

The effect of varying ionic strength at several $\mathrm{pH}$ values on the solubility of the isolated fraction was then examined. Table $\mathrm{V}$, illustrating the data obtained in four identical experiments, shows that the isolated fraction, similar to the fraction

TABLE V

Effect of pH and ionic strength on solubility of isolated heparin-precipitable fraction

\begin{tabular}{lcccc}
\hline \hline & \multicolumn{5}{c}{ Precipitate, gm. \% } \\
\cline { 2 - 5 } $\begin{array}{c}\text { Ionic } \\
\text { strength* }\end{array}$ & \multicolumn{4}{c}{$\mathrm{pH}$} \\
\cline { 2 - 5 } & 6.7 & 7.0 & 7.4 & 7.7 \\
\hline 0.05 & 0.33 & 0.32 & 0.32 & 0.31 \\
0.20 & 0.20 & 0.15 & 0.08 & 0.04 \\
0.35 & 0.03 & 0.01 & 0 & 0 \\
0.50 & 0.02 & 0 & 0 & 0 \\
& & & & 0
\end{tabular}

* Aliquots of twice-washed cold-precipitates from the pooled heparinized plasma of four acutely ill patients were dissolved at $37^{\circ} \mathrm{C}$ in phosphate buffers of the indicated $\mathrm{pH}$ and ionic strength. After 18 hours at $2^{\circ} \mathrm{C}$ the amount of precipitate was measured. 
TABLE VI

Effect of calcium and magnesium ions on precipitation from bivalent ion-depleted, heparinized plasma

\begin{tabular}{cc}
\hline \hline Treatment of plasma* & $\begin{array}{c}\text { Precipitate } \\
\mathbf{g m . \%}\end{array}$ \\
\hline a. Heparinized plasma, untreated & 0.30 \\
b. Bivalent ion-depleted heparinized plasma & \\
plus $\mathrm{CaCl}_{2}$ (final concentration, $\mathrm{mM} / \mathrm{ml}$.) & \\
0.000 & 0.19 \\
0.002 & 0.20 \\
0.003 & 0.27 \\
0.004 & 0.29 \\
0.005 & 0.30 \\
0.01 & 0.40 \\
c. Same plus $\mathrm{MgCl}_{2}$ (final concentration, $\mathrm{mM} / \mathrm{ml}$. ) & \\
0.005 & 0.31 \\
0.01 & 0.40
\end{tabular}

* Heparinized plasma was pooled and divided into aliquots. Na-cycled Dowex 50 was added to the plasma to remove bivalent ions. To $1.8 \mathrm{ml}$. of this plasma was added $0.2 \mathrm{ml}$. of the reagent indicated to give the final concentration shown, and the precipitate determined after 18 hours at $2^{\circ} \mathrm{C}$.

in plasma, increases in solubility with increasing ionic strength. The limits of this "salting in" effect are not shown in this experiment. In other experiments it was found that the isolated fraction could be precipitated by high concentrations of $\mathrm{NaCl}$.

\section{The effect of calcium and magnesium ions on pre- cipitation from heparinized plasma}

As shown in Table I (B), decalcified heparinized plasma yielded less precipitate than heparinized plasma alone. Since decalcification by treating the plasma with sodium-cycle Dowex 50 also reduced the amount of precipitate in heparinized plasma, it appeared that this effect was not due to the increased ionic strength provided by the decalcifying agents, but to binding of bivalent cations. The effect of replacing calcium or magnesium ions on HPF yield from plasma depleted of these cations was therefore investigated.

In the experiment summarized in Table VI, addition of calcium chloride to a final concentration between 0.004 and 0.005 millimol per $\mathrm{ml}$. resulted in a yield equivalent to that obtained from the original heparinized plasma, within the limits of experimental error. Calcium added to the cation-depleted plasma to 0.01 millimol per ml. resulted in a larger yield of precipitate than that occurring in the untreated plasma. The addition of magnesium ions to depleted plasma resulted in similar increases in precipitation.

\section{Evidence for a relationship between the heparin- precipitable fraction and fibrinogen}

In previous studies evidence that the heparinprecipitable fraction appearing in the plasma of endotoxin-treated rabbits was closely associated with or related to fibrinogen, depended upon a) absence from serum, b) partial clottability by thrombin, c) similar electrophoretic mobility, and d) disappearance in vivo along with circulating fibrinogen when high molecular weight acidic polymers having the property of precipitating fibrinogen in vitro were administered to endotoxintreated rabbits $(7,9)$. Inasmuch as the fraction was not demonstrable in normal rabbit plasma, appearing only after injection of bacterial endotoxin, it was concluded that the fraction differed qualitatively from fibrinogen (7).

Evidence that the heparin-precipitable fraction from humans resembles fibrinogen has been sought. As indicated in Table $\mathrm{I}$, the component is absent from the heparinized serum of patients whose heparinized plasma yields large amounts of precipitate. This and many similar negative observations on samples from ill patients indicate clearly that these precipitates are not coldprecipitating globulins of the type reported by Wintrobe and Buehl (14), Watson and Lerner (15), and others.

The clottability of the isolated fraction obtained from acutely ill patients varied between 41 and 63 per cent of the precipitable protein, as shown

TABLE VII

Clottability of heparin-precipitable fraction

\begin{tabular}{ccc}
\hline \hline Patient & $\begin{array}{c}\text { Precipitate* } \\
\text { gm. \% }\end{array}$ & $\begin{array}{c}\text { Clottable } \\
\text { protein } \\
\%\end{array}$ \\
\hline A & 0.73 & 41 \\
B & 0.57 & 44 \\
C & 0.54 & 61 \\
D & 0.43 & 44 \\
E & 0.27 & 63 \\
F & 0.04 & 50
\end{tabular}

* Twice-washed precipitates from heparinized plasma were redissolved in $\mathrm{pH} 7.4$ buffer and thrombin. The clottable protein is given as per cent of precipitable protein. 
in Table VII. Interpretation of these data is complicated by the antithrombic effect of heparin present in the complex; it can be concluded only that these represent minimum values for clottability.

The technique of zone paper electrophoresis at $37^{\circ} \mathrm{C}$ has been used to examine precipitates from a number of acutely ill patients. A typical pattern, shown in Figure 1, compares migration of the fraction after 6 hours at $37^{\circ} \mathrm{C}$ with heparinized plasma and heparinized serum run simultaneously from the same patient. It may be seen that the fraction migrates as a single band at approximately the same rate as fibrinogen. However, the precise mobilities have not as yet been determined, because of difficulties inherent in free electrophoresis at or near room temperature (16).

Sedimentation of the twice-washed and redis-

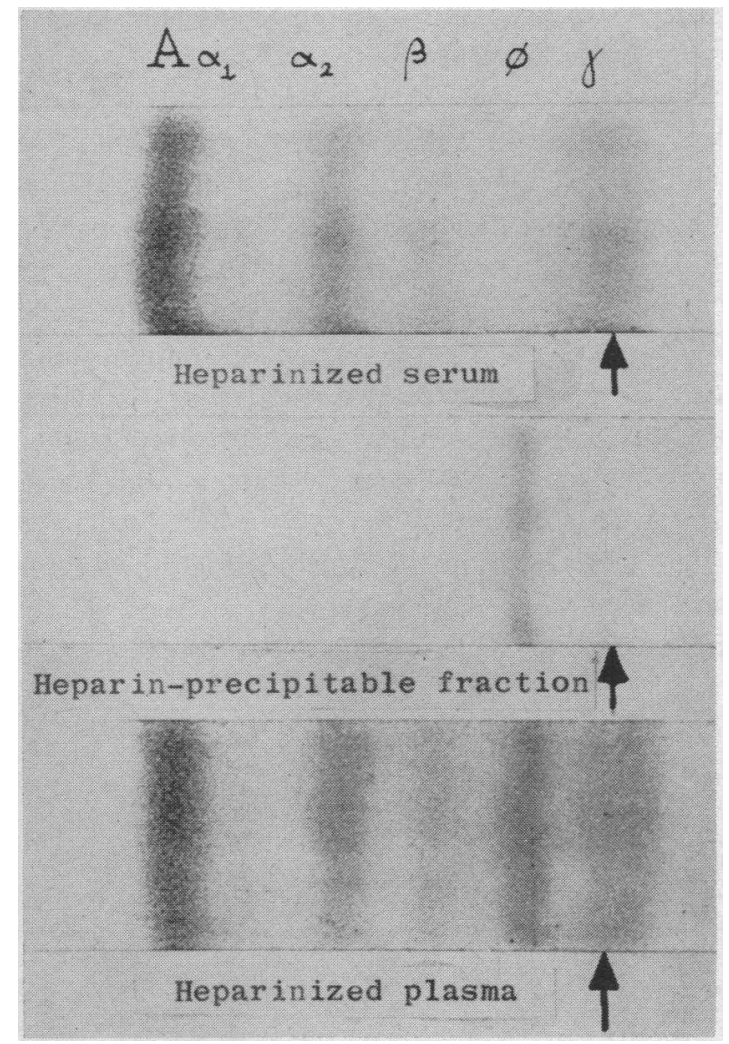

Fig. 1. Electrophoretic Migration of Simultaneously Obtained Heparinized Plasma, Heparinized Seruat, and Heparin-Precipitabie: Fraction ox Paper AT $37^{\circ} \mathrm{C}$, iN pH 8.6 Verunal Bufrek

Origin at arrow. The heparin-precipitable fraction migrates parallel to fibrinogen in the heparinized plasma.

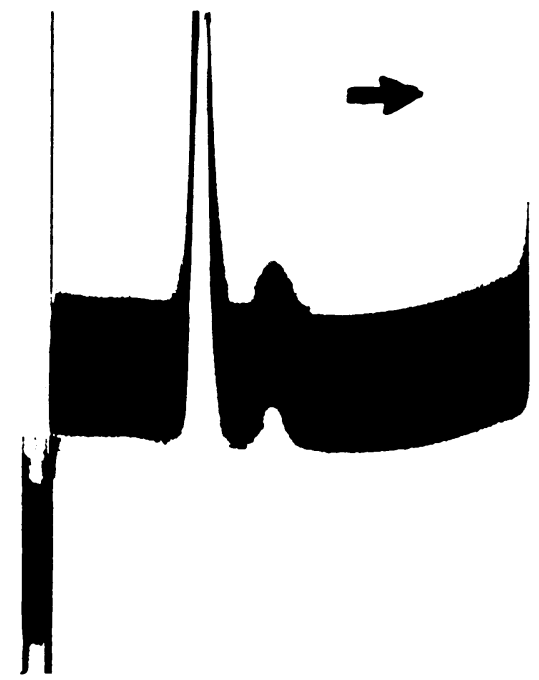

Fig. 2. Sedimentation Pattern of Heparin-Precipitable Fraction Obtained from an Acutely Ill Patient

Forty-eight minutes run at $28^{\circ} \mathrm{C}$ in $0.5 \mathrm{M} \mathrm{NaCl}$ at $59,670 \mathrm{rpm}$ in a Spinco Model E ultracentrifuge. The slower peak has sedimentation constant $\mathrm{S}_{20_{\mathrm{w}}}=7.9$; the faster peak, $\mathrm{S}_{{ }^{20} \mathrm{w}}=12.5$.

solved fraction determined in the analytical ultracentrifuge at $20^{\circ} \mathrm{C}$ shows two peaks. A typical pattern is shown in Figure 2. The slower moving peak, accounting for approximately 80 per cent of the protein in most patients studied has a sedimentation constant $\left(\mathrm{S}_{20_{\mathrm{w}}}\right)$ ranging between 7.9 and 8.3. This value is similar to that reported for human fibrinogen (17). The fast moving component has a sedimentation constant $\left(\mathrm{S}_{=\mathrm{n}_{\mathrm{w}}}\right)$ varying between 10.2 and 12.5 .

TABLE VIII

Influence of heparin on cold-solubility of isolated fibrinogen

\begin{tabular}{cccc}
\hline \hline Determination* & $\begin{array}{c}\text { Red Cross } \\
\text { Lot 47 }\end{array}$ & $\begin{array}{c}\text { Red Cross } \\
\text { Lot A50 }\end{array}$ & $\begin{array}{c}\text { Cutter } \\
\text { Lot E4530 }\end{array}$ \\
\hline Total protein $(\mathrm{gm} . \%)$ & 1.9 & 1.85 & 1.1 \\
\hline $\begin{array}{c}\text { Clottable protein (\% of } \\
\text { total protein) }\end{array}$ & 56.4 & 78.0 & 64.0 \\
$\begin{array}{c}\text { Heparin, cold-insoluble } \\
\text { protein (\% of total } \\
\text { protein) }\end{array}$ & 11.2 & 21.6 & 25.4 \\
$\begin{array}{c}\text { Cold-insoluble protein } \\
(\% \text { of total protein) }\end{array}$ & 2.7 & 3.8 & 5.4 \\
\hline
\end{tabular}

* Solutions of the dried preparations were made up to the protein concentration indicated; the clottability was determined, and remainder of the solution divided into two portions; to one aliquot, heparin, $0.2 \mathrm{mg}$. per $\mathrm{ml}$., was added; after 18 hours at $2^{\circ} \mathrm{C}$ the protein content of the twice-washed precipitates was determined. 


\section{Influence of heparin on solubility of isolated hu- man fibrinogen}

Heparin, $0.2 \mathrm{mg}$. per $\mathrm{ml}$., was added to aliquots of two lots of outdated Red Cross purified human fibrinogen, and one lot of Cutter human fibrinogen, to determine its effect on cold-solubility of the isolated protein. Other aliquots without heparin were examined simultaneously. The results of this experiment, given in Table VIII, indicate that after standing 18 hours at $2^{\circ} \mathrm{C}, 11.2$ and 21.6 per cent of the protein in the Red Cross fibrinogen precipitated, whereas 25.4 per cent of the other preparation was insoluble. Small amounts of cold-insoluble material precipitated without added heparin. It is clear from this experiment that the bulk of protein in these preparations is not insoluble in the presence of heparin at $2^{\circ} \mathrm{C}$, although up to 78 per cent is clottable.

\section{DISCUSSION}

These experiments define some of the attributes of a component of human plasma characterized by a low solubility in the presence of heparin or related acidic polymers. Evidence has been presented that the plasma component is present, but soluble in freshly drawn decalcified plasma. Addition of heparin decreases the solubility of the fraction so that it is demonstrable simply by chilling to $2^{\circ} \mathrm{C}$. The solubility of the isolated precipitable fraction is lowest in the presence of bivalent cations, at low temperature, low $\mathrm{pH}$, and low ionic strength. In its solubility properties, absence from serum, clottability, electrophoretic mobility, and sedimentation characteristics, human HPF appears, as in the case of rabbit HPF (7), to be very similar to fibrinogen. On the other hand, experiments in which heparin was added to "purified" fibrinogen preparations indicate that only a small percentage of the protein in fibrinogen preparations used for clinical purposes is insoluble at low temperatures in the presence of heparin.

Considerable evidence has accumulated (18-22) indicating that certain acidic polymers have a strong affinity for fibrinogen and the beta lipoproteins, less for other proteins, and that the complexes apparently formed between them exhibit solubility properties and resistance to denaturation not characteristic of the native protein.
Astrup and Piper (18) apparently were first to recognize and study such complexes systematically. They found that cellulose trisulfuric acid, polyanethol sulfonate, and similar high molecular weight compounds, precipitated fibrinogen from citrated plasma or purified fibrinogen preparations at room temperature. The effects of polymer concentration, $\mathrm{pH}$, ionic strength, and magnesium ions on this reaction were similar to those described above for cold-precipitation from heparinized plasma. They reported no precipitation occurring with chitin sulfate or heparin; however, their experiments were conducted at room temperature. Experiments not included in this paper confirm their observations with polyanethol sulfonate.

Ricketts (19), Walton $(20,21)$, and others (22) more recently have examined the interaction between dextran sulfates of varying molecular weight and fibrinogen. These studies have shown that dextran sulfates of intrinsic viscosities 0.24 to 0.4 added to fibrinogen solutions result in precipitation at $4^{\circ} \mathrm{C}$ but not at $37^{\circ} \mathrm{C}$. Dextran sulfates of higher intrinsic viscosity and presumably higher molecular weight, however, precipitated fibrinogen at $37^{\circ} \mathrm{C}$. Recently Kerby (23) reported that chondroitin sulfate added to citrated plasma from patients with inflammatory disease resulted in cold-precipitation of a polysaccharideprotein complex.

These various items of evidence indicating the affinity of high molecular weight sulfated polysaccharides for fibrinogen permit speculation on a possible physiological role of the protein which precipitates with heparin, as HPF, i.e., in the removal from the circulation of high molecular weight polysaccharides that arise from damage to ground substance. Such protein-polysaccharide complexes, if aggregated into macromolecular particles of sufficient size, would be immediately subject to removal by the cells of the reticuloendothelial system. Should the rate of complex formation exceed the capacity for removal by the R. E. system, deposition of the complexes, as fibrinoid, might occur. The experimental data available (24-26) lend support to this possibility.

Some properties of HPF closely resemble those of Fraction I-1, a cold-insoluble plasma component, described by Morrison, Edsall, and Miller (27), and more recently investigated by Edsall, 
Gilbert, and Scheraga (28). These workers found that Fraction I-1 was insoluble at $4^{\circ} \mathrm{C}$ at low $\mathrm{pH}$, low ionic strength in the presence of 0.5 per cent ethanol but soluble at $20^{\circ} \mathrm{C}$. Like HPF, Fraction I- 1 was up to 50 per cent clottable, and upon ultracentrifugal analysis was resolved into two components. The more abundant component had a sedimentation constant of 7 to $8.4 \mathrm{~S}$, that of purified fibrinogen; the minor component sedimented more rapidly with a constant from 9.7 to $12.2 \mathrm{~S}$. These values are similar to those obtained with HPF samples. Further studies (28) of the nonclottable fraction representing the residue of Fraction I-1 remaining after clotting with thrombin suggested that this was a globulin closely related to fibrinogen, perhaps a dimer. The relationship of the non-clottable fraction of HPF to this nonclottable globulin requires further investigation. A comparison of the $\mathrm{N}$-terminal amino acids of HPF, fibrinogen, fibrin, and cold-insoluble globulin is being made currently in this laboratory.

Three other fibrinogen-like proteins having solubility properties which resemble HPF have been described previously. Morrison (29) studied a component designated "contractinogen" obtained from the plasma of pregnant or acutely ill patients by precipitation with $16 \% / 3$ per cent saturated ammonium sulfate. Contractinogen was reversibly cold-insoluble and showed an unusual propensity to clot spontaneously, and then retract markedly. This protein, rather than the more soluble clottable fractions, was thought to be responsible for aggregation and settling of red blood cells in the determination of the erythrocyte sedimentation rate.

Another fibrinogen component, studied extensively by Lyons (30) and termed "fibrinogen $B$," has been characterized by its insolubility when combined with certain naphthoquinone derivatives. "Fibrinogen B" was reported to be present in significant amounts in a varied assortment of diseases, particularly infectious and thrombotic states, but not in normal individuals.

Recently, Korst and Kratochvil (31) reported a case of pulmonary malignancy and multiple thromboses associated with "cryofibrinogenemia." A component from this patient's plasma was found to be reversibly precipitable at low temperatures, clottable, rouleaux-promoting and betanaphtholprecipitable. Heparin augmented cold-precipita- tion of the component from citrated plasma (32). The sedimentation value for the major component of this fraction $\left(\mathrm{S}_{20 \mathrm{w}}=7.9\right)$ resembled fibrinogen (17); a minor component had an $S_{20}$ value of approximately 12 (estimated from published data). This "abnormal" fibrinogen resembles HPF in several ways, then, but apparently does not require the presence of heparin to precipitate at low temperatures. However, the possibility that an endogenous heparin-like component may have been present in their patient's circulation was not excluded. Where data are available, then, the close similarity of each of these "abnormal" fibrinogen fractions is striking.

Morrison (29) has suggested that contractinogen represents a qualitative alteration of fibrinogen, perhaps partial polymerization, occurring as a result of disease. A similar hypothesis was proposed in relation to the occurrence of HPF in experimental animals following endotoxin administration $(7,8)$. HPF in humans might also represent a polymer formed during the conversion of fibrinogen to fibrin, resembling those studied by Apitz (33), more recently by Donnelly, Laskowski, Notley, and Scheraga (34) and Casassa (35).

On the other hand, the possibility is not excluded that this group of fractions related to or associated with fibrinogen might represent a segment of the spectrum of fibrinogen-like proteins, each of which differs slightly from "pure" clottable protein, in solubility, and possibly in physiological function. Current studies of the relative turnover rates of this more insoluble fraction compared with the clottable fraction may illuminate this point.

\section{SUMMARY AND CONCLUSION}

Some of the physical and chemical properties of a fraction of human plasma which is characterized by cold-insolubility in the presence of heparin have been described. The data indicate that the fraction is a fibrinogen-like protein loosely combined with heparin, the resultant complex having altered solubility properties. Solubility of the fraction was found to be favored by increasing ionic strength, elevated temperature, alkaline $\mathrm{pH}$, and the absence of calcium or magnesium ions. The amount of cold-insoluble fraction obtained from a given plasma is a function of the heparin 
concentration. Evidence was obtained that the heparin-precipitable fraction is closely related to or associated with fibrinogen in that it is partially clottable, has similar mobility on electrophoresis, and is absent from serum. In the ultracentrifuge two components were found, the major fraction resembling fibrinogen, the minor component resembling the cold-insoluble, non-clotting component of Fraction I-1.

The possible relationships between heparinprecipitable fraction and previously reported fibrinogen-like proteins are discussed, and available data bearing on the possible nature and origin of the fraction are reviewed.

\section{ACKNOWLEDGMENT}

The authors are grateful for the able assistance of Dr. M. D. Olmanson, and Mrs. Donna Gellerman.

\section{REFERENCES}

1. Brunson, J. G., and Davis, R. L., Systemic fibrinoid diseases: Similarity to experimental lesions in rabbits. Bull. U. Hosp. \& Minn. Med. Found., 1955, 26, 362.

2. Craig, J. M., and Gitlin, D., Distribution of fibrin in human pathologic lesions using labeled fluorescent antifibrin serum. Federation Proc., 1955, 14, 401.

3. Thomas, L., and Good, R. A., Studies on the generalized Shwartzman reaction. I. General observations concerning the phenomenon. J. Exper. Med., 1952, 96, 605.

4. Brunson, J. G., Thomas, L., and Gamble, C. N., Morphologic changes in rabbits following the intravenous administration of meningococcal toxin. II. Two appropriately spaced injections; The rôle of fibrinoid in the generalized Shwartzman reaction. Am. J. Path., 1955, 31, 655.

5. Thomas, L., Brunson, J., and Smith, R. T., Studies on the generalized Shwartzman reaction. VI. Production of the reaction by the synergistic action of endotoxin with three synthetic acidic polymers (sodium polyanethol sulfonate, dextran sulfate, and sodium polyvinyl alcohol sulfonate). J. Exper. Med., 1955, 102, 249.

6. Brunson, J. G., Gamble, C. N., and Thomas, L., Morphologic changes in rabbits following the intravenous administration of meningococcal toxin. I. The effects produced in young and in mature animals by a single injection. Am. J. Path., 1955, 31, 489.

7. Thomas, L., Smith, R. T., and Von Korff, R., Studies on the generalized Shwartzman reaction. VII. The role of fibrinogen in the deposition of fibrinoid after combined injections of endotoxin and syn- thetic acidic polymer. J. Exper. Med., 1955, 102, 263.

8. Smith, R. T., Vauble, C., and Thomas, L., Experimental and clinical studies of fibrinogen and heparin precipitable fibrinogen, particularly as related to fibrinoid disease. Bull. U. Hosp. \& Minn. Med. Found., 1955, 26, 562.

9. Thomas, L., Smith, R. T., and Von Korff, R., Coldprecipitation by heparin of a protein in rabbit and human plasma. Proc. Soc. Exper. Biol. \& Med., 1954, 86, 813

10. Smith, R. T., and Thomas, L., Studies of the occurrence and significance of a heparin-precipitable protein in human plasma. Am. J. Dis. Child., 1955, 90, 598 (Abst.).

11. Smith, R. T., A heparin-precipitable fraction of human plasma. J. Lab. \& Clin. Med., 1955, 46, 953 (Abst.).

12. Weichselbaum, T. E., An accurate and rapid method for the determination of proteins in small amounts of blood serum and plasma. Am. J. Clin. Path., Tech. Suppl., 1946, 10, 40.

13. Saifer, A., and Newhouse, A., Photometric microdetermination of plasma fibrinogen with a thrombin-ninhydrin procedure. J. Biol. Chem., 1954, 208, 159.

14. Wintrobe, M. M., and Buehl, M. V., Hyperproteinemia associated with multiple myeloma with report of a case in which an extraordinary hyperproteinemia was associated with thrombosis of the retinal veins and symptoms suggesting Raynaud's disease. Bull. Johns Hopkins Hosp., 1933, 52, 156.

15. Watson, C. J., and Lerner, A. B., The clinical significance of cryoglobulinemia. Acta med. Scandinav. Suppl., 1947, 196, 489.

16. Johnson, P., and Shooter, E. M., Some of the factors involved in the use of the Tiselius electrophoresis apparatus at $20^{\circ}$ C. J. Colloid Sc., 1948, 3, 539.

17. Oncley, J. L., Scatchard, G., and Brown, A., Physicalchemical characteristics of certain of the proteins of normal human plasma. J. Phys. Chem., 1947, 51, 184.

18. Astrup, T., and Piper, J., Interaction between fibrinogen and polysaccharide polysulfuric acids. Acta physiol. Scandinav., 1946, 11, 211.

19. Ricketts, C. R., Interaction of dextran and fibrinogen. Nature, 1952, 169, 970.

20. Walton, K., Experiments with dextran sulfate as an anticoagulant. Proc. Roy. Soc. Med., 1951, 44, 563.

21. Walton, K. W., The biological behavior of a new synthetic anticoagulant (dextran sulfate) possessing heparin-like properties. Brit. J. Pharmacol., 1952, $7,370$.

22. Fletcher, F., Martin, L. E., and Ratcliffe, A. H., Interaction of macromolecules and fibrinogen. $\mathrm{Na}$ ture, 1952, 170, 319.

23. Kerby, G. P., Interactions between plasma proteins and acid mucopolysaccharides in rheumatoid arthritis. Am. J. Med., 1956, 20, 952 (Abst.). 
24. Hausman, R., and Dreyfus, P. M., Intracapillary precipitates produced in rabbits by means of sodium polyanetholsulfonate. Arch. Path., 1953, 56, 597.

25. Walton, K. W., Investigation of the toxicity of a series of dextran sulfates of varying molecular weight. Brit. J. Pharmacol., 1954, 9, 1.

26. Brunson, J. G., Davis, R. L., and Thomas, L., Morphologic changes in rabbits following the intravenous administration of meningococcal toxin. II. The effects produced by endotoxin in association with certain high molecular weight acid polymers. Am. J. Path., 1955, 31, 669.

27. Morrison, P. R., Edsall, J. T., and Miller, S. G., Preparation and properties of serum and plasma proteins. XVIII. The separation of purified fibrinogen from fraction I of human plasma. J. Am. Chem. Soc., 1948, 70, 3103.

28. Edsall, J. T., Gilbert, G. A., and Scheraga, H. A., The non-clotting component of the human plasma fraction I-1 ("cold-insoluble globulin"). J. Am. Chem. Soc., 1955, 77, 157.
29. Morrison, I. R., Qualitative changes in fibrinogen which influence the erythrocyte sedimentation rate and the clot retraction time. Am. J. M. Sc., 1946, 211, 325.

30. Lýons, R. N., Thiol-vitamin $K$ mechanism in the clotting of fibrinogen. Nature, 1945, 155, 633.

31. Korst, D. R., and Kratochvil, C. H., "Cryofibrinogen" in a case of lung neoplasm associated with thrombophlebitis migrans. Blood, 1955, 10, 945.

32. Korst, D. R., Personal communication.

33. Apitz, K., Uber Profibrin. II. Die Bildung von Profibrin bei der Denaturierung des Fibrinogens. Ztschr. f. d. ges. exper. Med., 1937, 102, 202.

34. Donnelly, T. H., Laskowski, M., Jr., Notley, N., and Scheraga, H. A., Equilibria in the fibrinogenfibrin conversion. II. Reversibility of the polymerization steps. Arch. Biochem. \& Biophys., $1955,56,369$.

35. Casassa, E. F., The conversion of fibrinogen to fibrin. XIX. The structure of the intermediate polymer of fibrinogen formed in alkaline solutions. J. Am. Chem. Soc., 1956, 78, 3980. 